\title{
Characteristics of the enteroaggregative Shiga toxin/ verotoxin-producing Escherichia coli O104:H4 strain causing the outbreak of haemolytic uraemic syndrome in Germany, May to June 2011
}

F Scheutz (fsc@ssi.dk)1,2, E Møller Nielsen², J Frimodt-Møller ${ }^{1,3}$, N Boisen ${ }^{1,2}$, S Morabito $^{4}$, R Tozzoli ${ }^{4}$, J P Nataro5, A Caprioli 4

1. World Health Organization Collaborating Centre for Reference and Research on Escherichia and Klebsiella, Department of Microbiological Surveillance and Research, Copenhagen, Denmark

2. Food-borne pathogens and typing, Department of Microbiological Surveillance and Research, Statens Serum Institut, Copenhagen, Denmark

3. Department of Clinical Microbiology, Hillerød Sygehus, Hillerød, Denmark

4. European Union Reference Laboratory for Escherichia coli, Department of veterinary public health and food safety, Istituto Superiore di Sanità, Rome, Italy

5. University of Virginia School of Medicine, Charlottesville, United States

Citation style for this article:

Scheutz F, Møller Nielsen E, Frimodt-Møller J, Boisen N, Morabito S, Tozzoli R, Nataro JP, Caprioli A. Characteristics of the enteroaggregative Shiga toxin/verotoxinproducing Escherichia coli $\mathrm{O}_{104}: \mathrm{H}_{4}$ strain causing the outbreak of haemolytic uraemic syndrome in Germany, May to June 2011.

Euro Surveill. 2011;16(24):pii=19889. Available online: http://www.eurosurveillance.org/ViewArticle.aspx?Articleld=19889

The Escherichia coli strain causing a large outbreak of haemolytic uraemic syndrome and bloody diarrhoea in Germany in May and June 2011 possesses an unusual combination of pathogenic features typical of enteroaggregative $E$. coli together with the capacity to produce Shiga toxin. Through rapid national and international exchange of information and strains the known occurrence in humans was quickly assessed. We describe simple diagnostic screening tools to detect the outbreak strain in clinical specimens and a novel real-time PCR for its detection in foods.

\section{Sequence of events}

Having received the first Early Warning Response System (EWRS) alert issued by the Robert Koch Institute (RKI) in Germany on 23 May about an increase in the number of patients presenting with haemolytic uraemic syndrome (HUS) and bloody diarrhoea caused by Shiga toxin-producing Escherichia coli (STEC) with more than 30 possible cases reported since the second week of May, the World Health Organization Collaborating Centre (WHO CC) for Reference and Research on Escherichia and Klebsiella at Statens Serum Institut (SSI) in Denmark issued an alert to the Danish $E$. coli network of regional hospitals on the same day. On 24 May, Hvidovre University hospital reported a German patient who had been diagnosed with Shiga toxin/verotoxin-producing E. coli (STEC/VTEC) and referred the strain to SSI. The WHO CC found that this first isolate was of serotype $0104: \mathrm{H}_{4}$ and produced Shiga toxin (Stx)/verotoxin (VT) as also reported by RKI. Referral from other regional hospitals identified the German outbreak strain in further patients in Denmark during the next days. This information was immediately shared by postings on the Urgent Inquiry Network (UIN) Epidemic Intelligence Information System (EPIS) hosted by the Food- and Waterborne Diseases and Zoonoses (FWD) Surveillance Network of the European Centre for Disease Control and Prevention (ECDC), and emails to FWD, the European Union Reference Laboratory for E. coli (EU-RL) and the two associated networks including public health (ECDC) and food safety (EU-RL) reference laboratories, the Global Food-borne Infections Network (GFN), Food Safety, WHO Geneva and the WHO Regional Office for Europe, and PulseNet at the United States (US) Centers for Disease Control and Prevention (CDC).

Having verified the specific characteristics of eight of the Danish outbreak strains, the WHO CC sent the index strain and the reference strain for the 0104 antigen to the EU-RL in Rome. The strains were received on 31 May and tested positive by the EU-RL using a novel real-time PCR developed at the EU-RL and its network for detection of $E$. coli strains of serotype $0_{104}: \mathrm{H}_{4}$. Thus, within a week, screening tools and a novel PCR protocol for detection of the outbreak strain in clinical specimens and in foods were developed, tested and shared with national as well as international networks. In return, members of the networks contributed with their existing knowledge of $E$. coli strains of serotype 0104: $\mathrm{H}_{4}$, thereby collectively adding to the existing knowledge of this pathogen and describing the relevant characteristics of the reported strains for public health investigation.

\section{The outbreak strain}

The Danish isolates were PCR-positive for the $\operatorname{aggR}$ gene, which is typical of enteroaggregative Escherichia coli (EAggEC). Further analysis showed that the outbreak strain (first eight isolates from Danish patients) 
were also positive for the following genes: $\operatorname{sig} A$, sepA, pic, aat $A$, aaiC, aap, as well as aggA, which encodes the major component of the AAF/I adhesin. AAF/I is a fimbrial organelle usually associated with a strong ability to form biofilms and haemagglutination with human erythrocytes. Preliminary testing at WHO CC showed that the isolates were moderate to good biofilm producers particularly in Dulbecco's minimum essential medium (DMEM) supplemented with $0.45 \%$ glucose, which is typical and defining for EAggEC strains. The outbreak strain was a typical E. coli: lactose-positive, sorbitol-fermenting and beta-glucuronidase-positive. Furthermore, the strain was positive for iutA encoding an aerobactin receptor found in $80 \%$ of extraintestinal pathogenic $E$. coli isolated from urosepsis [2] and negative for the STEC-associated adhesin (saa) and cytotoxin subtilase (subAB).

Taken together, these data indicate that the outbreak strain is indeed a typical EAggEC strain that has acquired the bacteriophage encoding Stx/VT. Using a novel protocol for subtyping of stx/vtx genes [3], we have shown that the gene encoding Stx/VT is stxza/vtxza.

Sequence analysis of the published stx2a/vtxza sequence (SRX067313 on http://www.ncbi.nlm.nih. gov/sra) showed $100 \%$ amino acid identity of the holotoxin to Stx2a/VT2a from E. coli $\mathrm{O}_{157} \mathrm{H} \mathrm{H}_{7}$ EDL933 isolated from Michigan ground beef in 1983 (accession number X07865 [4]) but differed by one nucleotide at position 867 ( $C$ instead of $\mathrm{T}$ ), making the nucleotide sequence identical to the sequence found in sorbitolfermenting $0_{157}$ strains from Germany in 2002 and 2005 (accession numbers AY143336 and AY143337, unpublished), DQ231589 and DQ231590 [5], and Scotland in 2006 (EU526759) [6]. This sequence variant of stx2a/vtxza has also been detected in isolates from seagulls (accession number AB030484, unpublished) and human isolates of different serotypes: E. coli O121:H19 from Canada (DQ143182 and DQ143183) [7] and Idaho, US (EF441611) [8], and 0111:H8 also from Idaho, US (EF441606) [8].

These findings could explain the unexpectedly high level of virulence in a STEC/VTEC strain negative for the attaching/effacing pathogenicity island. It is indeed conceivable that the enteroaggregative adherence phenotype could have allowed these E. coli 0104 strains to colonise the intestinal mucosa of the affected patients as efficiently as the typical eae-positive STEC/VTEC strains. The different mechanism of adhesion might also explain why this strain is more likely to cause severe disease in adults rather than in children, as would be usual for typical HUS-associated STEC/ VTEC: adults and children might differ in their susceptibility to the adherence and/or colonisation properties of this type of EAggEC strain. Obviously, elucidating this aspect requires dedicated studies and we cannot exclude that the different rates of HUS between adults and children observed in the current outbreak just reflect a difference in the exposures.

\section{Screening for the outbreak strain}

Plating clinical samples on extended-spectrum betalactamase (ESBL) plates, such as commercially available Tryptone Bile X-Glucuronide (TBX) medium will allow growth of the outbreak strain and inhibit the majority of other $E$. coli strains. Excellent growth of the index strain (only one of the strains has been tested so far) from the outbreak has also been observed as light red colonies on cefixime tellurite sorbitol MacConkey (CT-SMAC) plates at $37{ }^{\circ} \mathrm{C}, 41.5^{\circ} \mathrm{C}$ and $44^{\circ} \mathrm{C}$ (Jeppe Boel, personal communication, 3 June 2011). Since cefixime belongs to the class of cephalosporins, it seems likely that the strain can overcome the cefixime concentration in CT-SMAC, but apparently it is also able to overcome the tellurite concentration.

For quick screening of clinical samples, K9 antiserum for live slide agglutination can be used in both primary and secondary testing laboratories. This is because the $\mathrm{O}_{104} \mathrm{O}$ antigen is identical to the $\mathrm{K} 9$ capsular antigen [9]. The $\mathrm{Kg}$ antiserum is readily available from SSI Diagnostica, Hillerød, Denmark (ivdorders@ssi.dk) and described on the SSI website [10]. At SSI, we have agglutinated culture from confluent growth but pools of 5 to10 individual colonies can also be agglutinated. Immediate positive reactions indicating the presence of $E$. coli 0104 have all been confirmed by conventional serotyping of $\mathrm{O}$ and $\mathrm{H}$ antigen, presence of stx2a/vtx2a and lack of the eae gene. Based on our observations so far, all weak reactions have turned out to be negative for the outbreak strain. The strain can also be detected by a number of methods targeting the stx2/vtx2 gene by PCR, RT-PCR or commercial Stx/VT detection kits. The strain must also be negative for the eae gene and confirmed for $\mathrm{O}_{104}$.

Food samples should be enriched in Buffered Peptone Water (225 $\mathrm{ml}$ for $25 \mathrm{~g}$ test portion) and incubated for 18 to $24 \mathrm{~h}$ at $37^{\circ} \mathrm{C} \pm 1^{\circ} \mathrm{C}$. DNA extracted from a $1 \mathrm{ml}$ aliquot is purified and tested for the presence of $s t x / v t x$ genes (first step of the real-time PCR procedure described in the ISO/TS 13136:2011(E) method [11]).

Samples positive for stx/vtx genes (regardless of the presence of the eae gene) are tested for the 0104associated gene ( $\left.w z X \mathrm{O}_{104}\right)$ [12]. The $w z X \mathrm{O}_{104}$-positive enrichment cultures are plated onto two media: (i) MacConkey agar, or TBX, or any other medium suitable for $E$. coli isolation, and (ii) a more selective medium containing an antibiotic supplement. Colonies positive for stx/vtx genes are identified for the $\mathrm{O}_{104}$ antigenassociated gene $\mathrm{wzX} \mathrm{O}_{104}$ and the gene encoding the $\mathrm{H}_{4}$ flagellar antigen, $\mathrm{fliCH}_{4}$ [12]. Conventional serotyping can be performed by standard methods [13]. Other markers can be tested by either conventional or realtime PCR for further characterisation.

DNA from an outbreak strain provided by the Robert Koch Institute to be used as positive control in the PCR assays can be obtained from Istituto Superiore di Sanità (ISS) in Rome (crl.vtec@iss.dk). 
To the best of our knowledge, this unusual combination of virulence factors of STEC/VTEC and EAggEC has rarely been described in humans. A strain of serotype 0111:H2 [14] caused a small outbreak of HUS in France in 1995, but the episode involved children, as is typical for STEC/VTEC [15]. As in the present outbreak in Germany, the association of the French strains with severe disease (HUS) supports the view that this unusual combination of virulence factors might confer a very high degree of virulence.

\section{Serotype 0104:H4}

Sporadic cases of stx2/vtx2-positive $E$. coli serotype 0104: $\mathrm{H}_{4}$ have been reported. These reports include two isolates from patients with HUS in Germany in 2001 [16], one in France in 2004 (data from the dedicated EU surveillance network Enter-net; not including clinical information), one from a case of HUS in Korea in 2005 [17], two HUS cases in the Republic of Georgia in 2009 (unpublished information provided via PulseNet, US (DC), and one uncomplicated case of diarrhoea in Finland in 2010 (reported to FWD on EPIS). The isolates from Germany 2001, Finland 2010 and the Republic of Georgia 2009 were EAggEC and STEC/VTEC.

The strain from the Republic of Georgia had the following characteristics: serotype $0104: \mathrm{H}_{4}$, Shiga toxin subtype stx2a, eae-negative, haemolysin-negative, aatA-positive (EAggEC marker), susceptible to ceftriaxone (unlike the current outbreak strain), sorbitol-, lactose-, and beta-glucuronidase-positive, biochemically consistent with E. coli, Shiga toxin production on the low end of the spectrum, similar to that of the German strain (Peter Gerner-Smidt, personal communication 7
June 2011 from PulseNet, US CDC, and the Georgian team of investigators). At this time, we do not have further information on the remaining 0104: $\mathrm{H}_{4}$ STEC/VTEC isolates from France and Korea.

In general, we have limited knowledge on EAggEC of this serotype: The archetype isolate for the aggregative adherence fimbriae type III (AAF/III, encoded by the agg3A gene) is strain 55989, which was isolated during a study of EAggEC as a cause of persistent diarrhoea in African patients infected with human immunodeficiency virus (HIV) $[18,19]$. In a recent study of childhood diarrhoea in Mali, we identified Stx/ VT-negative EAggEC 0104: $\mathrm{H}_{4}$ in three children with moderate to severe diarrhoea and from three healthy controls (unpublished data). The three EAggEC strains isolated from these cases were PCR-positive for different combinations of aggR, aatA, aaiC, aap, astA, sepA, pic, sigA, aggA, agg3 $C$ and agg3A.

We have compared the pulsed-field gel electrophoresis (PFGE) profiles of the available E. coli $\mathrm{O}_{104}: \mathrm{H}_{4}$ isolates to elucidate the diversity within this serotype, irrespective of the virulence profile. PFGE typing using the enzymes $X b a l$ and $B \mid n l$ showed that the serotype O104: $\mathrm{H} 4$ is diverse (Figure). For $\mathrm{Xbal}$, a high similarity of $>95 \%$ was seen for the 2011 German outbreak isolates (isolated in Denmark, Germany and the US) and one of the isolates from Republic of Georgia. A large cluster of isolates with $>90 \%$ similarity included the German outbreak strain, the two Georgian cases from 2009, the isolate from the Finnish patient (all stx2a/ vtx2a and EAggEC) as well as three of the stx/vtx-negative EAggEC isolates from patients in Mali. The profiles of five of the stx/vtx-negative EAggEC isolates showed

\section{FIGURE}

PFGE profiles (XbaI and BlnI) of Escherichia coli O104 compared with four isolates from the outbreak of haemolytic uraemic syndrome in Germany, May to June 2011

PFGE-Xbal PFGE-BInl Year Country Pathotype

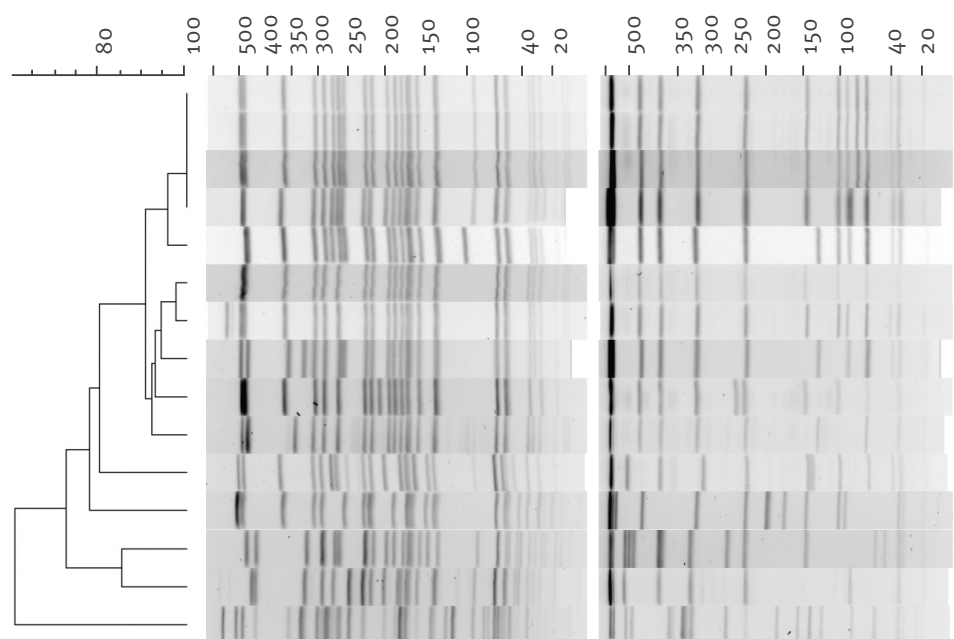

$\begin{array}{lll}2011 & \text { Denmark } & \text { EAggEC-VTEC } \\ 2011 & \text { Denmark } & \text { EAggEC-VTEC } \\ 2011 & \text { Germany } & \text { EAggEC-VTEC } \\ 2011 & \text { US } & \text { EAggEC-VTEC } \\ 2009 & \text { Georgia } & \text { EAggEC-VTEC } \\ 2009 & \text { Mali } & \text { EAggEC } \\ 2010 & \text { Finland } & \text { EAggEC-VTEC } \\ 2009 & \text { Georgia } & \text { EAggEC-VTEC } \\ 2009 & \text { Mali } & \text { EAggEC } \\ 2009 & \text { Mali } & \text { EAggEC } \\ 2000 & \text { Denmark } & \text { EAggEC } \\ 2009 & \text { Mali } & \text { EAggEC } \\ 2001 & \text { C. African Rep. } & \text { EAggEC } \\ 2009 & \text { Mali } & \text { EAggEC } \\ 2009 & \text { Mali } & \text { EAggEC }\end{array}$

C. African Rep: Central African Republic; CDC: Centers for Disease Control and Prevention; PFGE: pulsed-field gel electrophoresis; RKI: Robert Koch Institute; US: United States.

PFGE profiles (Xbal and Blnl) using the E. coli non-0157 PulseNet protocol (www.pulsenetinternational.com). Dendrogram based on analysis of the Xbal profiles. All isolates are EAggEC $0_{104}: \mathrm{H}_{4}$ with and without stx2/vtx2 gene. German outbreak isolates are from patients infected in May 2011 in Germany and diagnosed in Denmark, the US (profiles provided by PulseNet, US CDC) and Germany (strain provided by RKI,

Germany). 0104: $\mathrm{H}_{4}$ isolates from Mali are from children with and without diarrhoea. 
major differences from the outbreak strain (Figure). The 11 Danish PFGE-typed isolates related to the German outbreak had indistinguishable $\mathrm{Xbal}$ profiles. One isolate from a case infected in Germany and diagnosed in the US had a minor variation in the Bln/ profile (profile provided by PulseNet, US CDC) (Figure).

\section{General characteristics of EAggEC}

EAggEC is a pathotype of diarrhoeagenic $E$. coli defined as $E$. coli that do not secrete the heat-stable or heatlabile toxins of enterotoxigenic E. coli (ETEC), and by its characteristic aggregative or 'stacked brick' pattern (AA) of adherence to HEp2-cells in culture [20]. This property is usually due to the presence of aggregative adherence fimbriae (AAF), whose expression is regulated by the aggR gene, located on the large EAggEC virulence plasmid termed pAA [21]. EAggEC infections are usually associated with watery diarrhoea, which is often persistent [20]. Illness results from a complex interaction between pathogen and host, which implicates the initial adherence of the bacteria to the epithelium of terminal ileum and colon, by virtue of the aggregative adherence fimbriae (characteristic aggregative pattern), followed by a damage/secretion stage manifested by cytokine release, mucosal toxicity, intestinal secretion and induction of mucosal inflammation [22-26].

EAggEC is best known for its role in persistent diarrhoea (>14 days) in infants and children in developing countries. Studies in Mongolia [27], India [28], Brazil [29,30], Nigeria [31,32], Israel [33], Venezuela [34], Congo [35] and many other countries, have identified EAggEC as a highly prevalent (often the most prevalent) E. coli pathotype in infants. Further, the role of EAggEC as an important pathogen in AIDS patients continues to develop, and EAggEC now ranks among the most important enteric pathogens in this population group $[36,37]$. In a recent review of all published studies of traveller's diarrhoea, EAggEC was in aggregate second only to ETEC as the most common pathogen [38].

The first reported EAggEC outbreaks occurred in Mexico City before 1993 (year unpublished) where persistent diarrhoea was reported. Five of the infected children died as a consequence of the diarrhoea. Both outbreaks occurred in the malnutrition ward of a paediatric hospital [39], demonstrating that EAggEC is not exclusively a disease of infants under the age of 12 months [40]. Itoh et al. described a massive outbreak of EAggEC diarrhoea among Japanese children in 1993 affecting nearly 2,700 patients [41]. Another EAggEC outbreak was reported in a Serbian nursery in 1995 [42] in which 16 newborn babies (duration of illness 3-9 days) and three infants (18-20 days) developed diarrhoea accompanied by pyrexia and weight loss. Outbreaks have also been reported among adults in the United Kingdom [43] and a small outbreak of EAggEC serotype 092: $\mathrm{H}_{33}$ was reported in Italy in which pecorino cheese (unpasteurised milk) was epidemiologically implicated [44]. As these outbreaks suggest, EAggEC is capable of causing diarrhoea in adults and children, even in the absence of Stx/VT. We believe that this pre-existing diarrhoeagenic and outbreak potential, coupled with the highly virulent Stx/VT, has resulted in a hypervirulent strain currently circulating in Germany. It should also be noted that EAggEC are common in all populations of the world, industrialised and developing, but that no animal reservoir has been described. This observation suggests the startling possibility that this new 0104 stain may have the capacity to persist among human populations, perhaps indefinitely.

\section{Conclusions}

The rapid exchange of information, strains and DNA fingerprints within existing national and international public health and food safety networks has been vital in the quick and alternative assessment of the public health significance of the strain causing the outbreak of HUS in Germany in May and June 2011. The combined contributions have resulted in major findings including:

- the characterisation of an unusual combination of pathogenic features typical of EAggEC combined with the capacity to produce Shiga toxin in the outbreak strain;

- recommendations for simple diagnostic screening tools for primary laboratory detection of the outbreak strain in clinical specimens;

- a novel real-time PCR protocol for detection of E. coli O104: $\mathrm{H}_{4}$ in foods;

- presentation of the known occurrence and clinical presentation in humans and the likely reservoir.

We hope that this report will help to strengthen existing networks, inspire the development of new networks and improve food safety in the future when new or emerging bacterial pathogens may occur in the food chain.

\section{Acknowledgements}

The authors wish to thank all contributors that have shared ideas and information with the WHO Collaborating Centre for Reference and Research on Escherichia and Klebsiella and the EU Reference Laboratory for E. coli during the course of this outbreak, in particular the following institutions, hospitals and individuals:

The 2009 Republic of Georgia HUS investigation team (South Caucasian Field Epidemiology and Laboratory Training Program (FELTP), National Center of Disease Control, Infectious Diseases, AIDS and Clinical Immunology Research Center and the United States Centers for Disease Control and Prevention): O Chokoshvili, K Lomashvili, N Malakmadze, M Lashqarashvili, N Chitadze, L Tevzadze, M Geleishvili, E Maes, T Rush, P Imnadze, T Tsertsvadze, NA Strockbine and R Mody.

We further wish to acknowledge:

Jeppe Boel, National Food Institute, Copenhagen, Denmark, Peter Gerner-Smidt and Chris Bailey, PulseNet, CDC, US,

Anja Siitonen and Taru Lienemann, Bacteriology Unit, National Institute for Health and Welfare (THL), Helsinki, Finland,

Rita Prager and Angelika Fruth, Robert Koch-Institute, Branch Wernigerode, NRC Salmonella and other bacterial enterics, Division of Bacterial Infections, Wernigerode, Germany,

Patrick Fach, French Agency for Food, Environmental and Occupational Health (Anses), Food Safety Laboratory, Maisons-Alfort, France, 
Roger Stephan and Herbert Hächler, Institute for food safety and hygiene, University of Zurich, Zurich, Switzerland,

The Danish E. coli network:

Bente Olesen, Hillerød Sygehus, Jørgen Engberg, Sygehus Vestsjælland, Katharina EP Olsen, Department for Microbiological Diagnostics, SSI, Alice Friis-Møller, Hvidovre Hospital, Hanne Marie Holt, Odense Universitetshospital, Lene Graff Sørensen, Sydvestjysk Sygehus, Tove Ejlertsen, Aalborg Sygehus Syd, Hanne Wiese Hallberg, Herlev Hospital, Lars Lemming, Århus Universitetshospital, Skejby, Dorthe Ørnskov, Vejle sygehus, Poul Kjældgaard, Sønderborg sygehus.

The technical assistance of Susanne Jespersen, Pia Møller Hansen and Charlotte Hoe, WHO CC, SSI is highly appreciated.

\section{Editorial note:}

This article was published as an e-alert on 14 June 2011, ahead of the regular Eurosurveillance issue.

\section{References}

1. Frank C, Faber M, Askar M, Bernard H, Fruth A, Gilsdorf A, et al. Large and ongoing outbreak of haemolytic uraemic syndrome, Germany, May 2011. Euro Surveill. 2011;16(21). pii:19878. Available from: http://www.eurosurveillance.org/ViewArticle. aspx?Articleld $=19878$

2. Johnson JR, Stell AL. Extended virulence genotypes of Escherichia coli strains from patients with urosepsis in relation to phylogeny and host compromise. J Infect Dis. 2000;181(1):261-72.

3. World Health Organization Collaborating Centre for Reference and Research on Escherichia and Klebsiella. Identification of three vtx1 and seven vtx2 subtypes of Verocytotoxin encoding genes of Escherichia coli by conventional PCR amplification. Copenhagen: Statens Serum Institut. [Accessed 11 Jun 2011] Available from: http://www.ssi.dk/English/PublicHealth/ National\%2oReference\%2oLaboratories/ /media/Indhold/ EN\%20-\%20engelsk/Public\%2oHealth/National\%20 Reference\%20Laboratories/vtx\%2odetection $\% 20 \% 20$ subtyping\%2oprotocol_EQA-2010-11_rev4.ashx

4. Jackson MP, Neill RJ, O’Brien AD, Holmes RK, Newland JW. Nucleotide sequence analysis and comparison of the structural genes for Shiga-like toxin I and Shiga-like toxin II encoded by bacteriohages from Escherichia coli 933. FEMS Microbiol Lett. 1987 September. 1987;44(1):109-14.

5. Bielaszewská M, Prage R, Zhang W, Friedrich AW, Mellmann $A$, Tschäpe $H$, et al. Chromosomal dynamism in progeny of outbreak-related sorbitol-fermenting enterohemorrhagic Escherichia coli 0157:NM. Appl Environ Microbiol. 2006;72(3):1900-9.

6. Rosser T, Dransfield T, Allison L, Hanson M, Holden N, Evans J, et al. Pathogenic potential of emergent sorbitol-fermenting Escherichia coli 0157:NM. Infect Immun. 2008;76(12):5598-607.

7. Gilmour MW, Tracz DM, Andrysiak AK, Clark CG, Tyson $\mathrm{S}$, Severini A, et al. Use of the espZ gene encoded in the locus of enterocyte effacement for molecular typing of shiga toxin-producing Escherichia coli. J Clin Microbiol. 2006;44(2):449-58.

8. Lee JE, Reed J, Shields MS, Spiegel KM, Farrell LD, Sheridan PP. Phylogenetic analysis of Shiga toxin 1 and Shiga toxin 2 genes associated with disease outbreaks. BMC Microbiol. 2007;7:109.

9. Orskov F, Orskov I. Serotyping of Escherichia coli. Meth Microbiol.1984;14:43-112.

10. Use K9 serum to screen for E. coli 0104. Copenhagen: Statens Serum Institut; 30 May 2011. Available from: http://www. ssi.dk/English/SSI\%20Diagnostica/SSI\%20Diagnostica\%20 news $/ 2011 /$ Use $\% 20 K 9 \% 20$ serum $\% 2$ oto $\% 20$ screen $\% 2$ ofor $\% 20$ E\%20coli\%200104.aspx

11. Microbiology of food and animal feeding stuffs - Horizontal method for the detection of Shiga toxin-producing Escherichia coli (STEC) belonging to $0_{157}, 0_{111}, 0_{2} 6,0103$ and $0_{145}$ serogroups - Qualitative real-time polymerase chain reaction (PCR)-based method. Geneva: International Organization for Standardization; 2009. ISO/WD TS 13136. [Accessed 13 Jun 2011]. Available from: http://www.iso.org/iso/iso_catalogue/ catalogue_tc/catalogue_detail.htm?csnumber $=53328$
12. EU Reference Laboratory for E.coli. EU Reference Laboratory for E.coli. (EU-RL VTEC). Detection and identification of verocytotoxin-producing Escherichia coli (VTEC) 0104: $\mathrm{H}_{4}$ in food by real Time PCR. Rome: Istituto Superiose di Sanità; 2 Jun 2011. Available from: http://www.iss.it/binary/vtec/cont/ Lab_Proc_VTEC_0104.pdf

13. Standard Operational Procedure for $\mathrm{O}$ and $\mathrm{H}$ serotyping and reference strains. Copenhagen: Statens Serum Institut; 30 May 2011. Available from: http://www.ssi.dk/English/PublicHealth/ National\%20Reference\%20Laboratories/ /media/Indhold/ EN\%20-\%20engelsk/Public\%20Health/National\%20 Reference $\% 2$ Laboratories/Standard $\% 20$ Operation $\% 20$ Procedures $\% 2$ ofor $\% 200 \% 20 \% 20 \mathrm{H} \% 2$ oserotyping $\% 20$ and $\% 20$ reference $\%$ 20strains.ashx

14. Morabito S, Karch H, Mariani-Kurkdjian P, Schmid H, Minelli $\mathrm{F}$, Bingen E, et al. Enteroaggregative, shiga toxin-producing Escherichia coli $0111: \mathrm{H} 2$ associated with an outbreak of hemolytic-uremic syndrome. J Clin Microbiol.1998;36(3):840-2.

15. Boudailliez B, Berquin P, Mariani-Kurkdjian P, Ilef D, Cuvelier B, Capek I, et al. Possible person-to-person transmission of Escherichia coli 0111- associated hemolytic uremic syndrome. Pediatr Nephrol. 1997;11(1):36-9.

16. Mellmann A, Bielaszewská M, Kock R, Friedrich AW, Fruth A, Middendorf $B$, et al. Analysis of collection of hemolytic uremic syndrome-associated enterohemorrhagic Escherichia coli. Emerg Infect Dis. 2008;14(8):1287-90.

17. Bae WK, Lee YK, Cho MS, Ma SK, Kim SW, Kim NH, et al. A case of hemolytic uremic syndrome caused by Escherichia coli 0104:H4. Yonsei Med J. 2006;47(3):437-9.

18. Bernier C, Gounon P, Le Bouguenec C. Identification of an aggregative adhesion fimbria (AAF) type III-encoding operon in enteroaggregative Escherichia coli as a sensitive probe for detecting the AAF-encoding operon family. Infect Immun. 2002;70(8):4302-11.

19. Mossoro C, Glaziou P, Yassibanda S, Lan NT, Bekondi C, Minssart $\mathrm{P}$, et al. Chronic diarrhea, hemorrhagic colitis, and hemolytic-uremic syndrome associated with HEp-2 adherent Escherichia coli in adults infected with human immunodeficiency virus in Bangui, Central African Republic. Clin Microbiol. 2002;40(8):3086-8.

20. Nataro JP. Kape JB. Diarrheagenic Escherichia coli. Clin Microbiol Rev. 1998;11(1):142-201.

21. Nataro JP. Enteroaggregative Escherichia coli pathogenesis. Curr Opin Gastroenterol. 2005;21(1):4-8.

22. Harrington SM, Strauman MC, Abe CM, Nataro JP. Aggregative adherence fimbriae contribute to the inflammatory response of epithelial cells infected with enteroaggregative Escherichia coli. Cell Microbiol. 2005;7(11):1565-78.

23. Bouckenooghe AR., DuPont HL, Jiang ZD, Adachi J, Mathewson J, Verenkar MP, et al. Markers of enteric inflammation in enteroaggregative Escherichia coli diarrhea in travelers. Am J Trop Med Hyg. 2000;62(6):711-3.

24. Jiang ZD, Greenberg D, Nataro JP, Steffen R, DuPont HL. Rate of occurrence and pathogenic effect of enteroaggregative Escherichia coli virulence factors in international travelers. Clin Microbiol. 2002;40(11):4185-90.

25. Steiner TS, Lima AA, Nataro JP, Guerrant RL. Enteroaggregative Escherichia coli produce intestinal inflammation and growth impairment and cause interleukin-8 release from intestinal epithelial cells. J Infect Dis. 1998;177(1):88-96.

26. Steiner TS, Nataro JP, Poteet-Smith CE, Smith JA, Guerran RL. Enteroaggregative Escherichia coli expresses a novel flagellin that causes IL- 8 release from intestinal epithelial cells. I Clin Invest. 2000;105(12):1769-77.

27. Sarantuya J, Nishi J, Wakimoto N, Erdene S, Nataro JP, Sheikh J, et al. Typical enteroaggregative Escherichia coli is the most prevalent pathotype among E. coli strains causing diarrhea in Mongolian children. J Clin Microbiol. 2004;42(1):133-9.

28. Dutta S, Pal S, Chakrabarti S, Dutt P, Manna B. Use of PCR to identify enteroaggregative Escherichia coli as an important cause of acute diarrhoea among children living in Calcutta, India. J Med Microbiol. 1999;48(11):1011-6.

29. Piva IC, Pereira AL, Ferraz UR, Silva RS, Vieira AC, Blanco JE, et al. Virulence markers of enteroaggregative Escherichia coli isolated from children and adults with diarrhea in Brasilia, Brazil. J Clin Microbiol. 2003;41(5):1827-32.

30. Zamboni A, Fabbricotti SH, Fagundes-Neto U, Scaletsky IC. Enteroaggregative Escherichia coli virulence factors are found to be associated with infantile diarrhea in Brazil. J Clin Microbiol. 2004;42(3):1058-63.

31. Okeke IN, Lamikanra A, Czeczulin J, Dubovsky F, Kaper JB, Nataro JP. Heterogeneous virulence of enteroaggregative Escherichia coli strains isolated from children in southwest Nigeria. J Infect Dis. 2000;181(1):252-60. 
32. Okeke IN, Lamikanra A, Steinrück H, Kaper JB. Characterization of Escherichia coli strains from cases of childhood diarrhea in provincial southwestern Nigeria. J Clin Microbiol. 2000;38(1):7-12.

33. Shazberg G, Wolk M, Schmidt H, Sechter I, Gottesman G, Miron D. Enteroaggregative Escherichia coli serotype $0126: \mathrm{H}_{27}$, Israel. Emerg Infect Dis. 2003;9(9):1170-3.

34. Gonzalez R, Diaz C, Marino M, Cloralt R, Pequeneze M, PerezSchael I. Age-specific prevalence of Escherichia coli with localized and aggregative adherence in Venezuelan infants with acute diarrhea. J Clin Microbiol. 1997;35(5):1103-7.

35. Jalaluddin S, De Mol P, Hemelhof W, Bauma N, Brasseur $D$, Hennart P, et al. Isolation and characterization of enteroaggregative Escherichia coli (EAggEC) by genotypic and phenotypic markers, isolated from diarrheal children in Congo. Clin Microbiol Infect. 1998;4(4):213-9.

36. Wanke CA, Mayer H, Weber R, Zbinden R, Watson DA, Acheson $D$, et al. Enteroaggregative Escherichia coli as a potential cause of diarrheal disease in adults infected with human immunodeficiency virus. J Infect Dis. 1998;178(1):185-90.

37. Wanke CA, Gerrior J, Blais V, Mayer H, Acheson D. Successful treatment of diarrheal disease associated with enteroaggregative Escherichia coli in adults infected with human immunodeficiency virus. J Infect Dis. 1998;178(5):1369-72.

38. Shah N, DuPont HL, Ramsey DJ. Global etiology of travelers' diarrhea: systematic review from 1973 to the present. Am J Trop Med Hyg. 2009;80(4):609-14.

39. Eslava C, Villaseca J, Morales R, Navarro A, Cravioto A. Identification of a protein with toxigenic activity produced by enteroaggregative Escherichia coli. Abstracts of the 93rd General Meeting of the American Society for Microbiology 1993. Washington, DC: American Society for Microbiology; 1993. B-105; p. 44.

40. Behrman R, Kliegman R. Nelson Essentials of pediatrics. 4th ed. Philadelphia: WB Saunders Company; 2002.

41. Itoh Y, Nagano I, Kunishima M, Ezaki T. Laboratory investigation of enteroaggregative Escherichia coli 0 untypeable:H10 associated with a massive outbreak of gastrointestinal illness. J Clin Microbiol. 1997;35(10):2546-50.

42. Cobeljic M, Miljkovic-Selimovic B, Paunovic-Todosijevic D, Velickovic Z, Lepsanovic Z, Zec N, et al. Enteroaggregative Escherichia coli associated with an outbreak of diarrhoea in a neonatal nursery ward. Epidemiol Infect. 1996;117(1):11-6.

43. Smith HR, Cheasty T, Rowe B. Enteroaggregative Escherichia coli and outbreaks of gastroenteritis in UK. Lancet. 1997;350(9080):814-5.

44. Scavia G, Staffolani M, Fisichella S, Striano G, Colletta S, Ferri G, et al. Enteroaggregative Escherichia coli associated with a foodborne outbreak of gastroenteritis. J Med Microbiol. 2008;57(Pt 9):1141-6. 